\title{
A Study of Serum Uric Acid Levels in Acute Ischemic Stroke Patients Admitted in Tertiary Care Hospital At Tirupati
}

\author{
S Rangavenamma ${ }^{1}$, Goduguchintha Lepakshi ${ }^{2}$, Nagatham Padmaja ${ }^{3}$ \\ ${ }^{1}$ Post Graduate, Dept. Of Medicine, S.V. Medical College, Tirupathi, India \\ ${ }^{2}$ Professor And HOD, Dept. Of Medicine, S.V. Medical College, Tirupathi, India \\ ${ }^{3}$ Asst. Professor, Dept. Of Medicine, S.V. Medical College, Tirupathi, India
}

\begin{abstract}
It is unclear whether Serum Uric Acid [SUA] promotes or protects against cerebrovascular disease. Present study was done to estimate uric acid levels and its association in patients of acute ischemic stroke.

Method: Total 100 consecutive patients (50 males and 50 females) with first episode of stroke as evidenced by CT scan within 48 hours were chosen for the study.The serum uric acid was estimated by the Uricase method. The patients were further evaluated for the presence of additional risk factors like hypertension, diabetes mellitus, coronary heart disese [CAD],smoking and alcoholism.

Results: Out of total 100 patients, 50 were males and 50 were females. The age of the patients in the present study were from 40 years to 84 years with mean age of 59.8 years. Mean serum uric acid level in patients were studied $5.58 \pm 1.68 \mathrm{mg} / \mathrm{dl}$ and about $25 \%$ patients were hyperuricemic. As age advances the uric acid level also rised with the ' $p$ ' of $<0.001$. Among diabetics the mean uric acid value was $6.12 \pm 1.64 \mathrm{mg} / \mathrm{dl}$ while among non diabetics it was $5.02 \pm 1.54 \mathrm{mg} / \mathrm{dl}$, among in CAD patients it was $6.5 \pm 1.9 \mathrm{mg} / \mathrm{dl}$ and in those without CAD was $5.1 \pm 1.4 \mathrm{mg} / \mathrm{dl}$; Among the patients with large infarct was $7.2 \mathrm{mg} / \mathrm{dl}$ compared to those with small infarct was $4.816 \mathrm{mg} / \mathrm{dl}$ and thus established a statistically significant relationship ( $p$ value of < 0.0001). The present study didn"t show any significant association between hypertension, hyperlipidemia, smoking, alcoholism and uric acid.

Conclusions: The prevalence of hyperuricemia in acute ischemic stroke patients in the present study was 25\%. There was a statistically significant association between levels of uric acid and age, diabetes mellitus, CAD, larger infarct size. There was no stastically a signicant association between hypertension, hyperlipidemia, smoking, alcoholism and uric acid levels.
\end{abstract}

Keywords: Serum uric acid, acute ischemic stroke

\section{Introduction}

Stroke is the second leading cause of death worldwide, causing 6.2 million deaths in $2011^{1}$.Stroke entails a high socio economic burden due to increased morbidity and mortality. Early identification of individuals at risk could be of help in primary prevention strategies. ${ }^{2}$ The role of serum uric acid (SUA) levels as an independent risk factor for vascular disease has been questioned for decades. ${ }^{3}$ Evidence from epidemiological studies suggests that elevated SUA levels may predict an increased risk for cerebrovascular events including stroke. ${ }^{3,4}$

In some studies serum uric acid has been linked to prognosis of patient with acute ischemic stroke. Evidence suggests that increased level of uric acid is bad prognostic factor in patients with acute ischemic stroke while some studies suggests increased level of serum uric acid as protective in patient with acute ischemic stroke. ${ }^{5,6}$

In this respect SUA levels estimation could be used as serum marker in selecting and appropriately caring for subjects at risk. As there are few studies in India on the role of SUA in acute ischemic stroke, hence a study on this aspects likely to be fruitful.

\section{Materials And Methods}

A cross sectional observational hospital based study was conducted on 100 patients of acute ischemic stroke who presented to the emergency department of medicine, Sri Venkateswara Medical College, Tirupathi, during the period of 10 months from $1^{\text {st }}$ December, 2014 to $31^{\text {st }}$ October, 2015.

\subsection{Inclusion criteria}

1. Patients with first episode of stroke and stroke are documented with CT scan taken within 48 hours of onset of symptoms of focal neurological deficit.

2. Patients willing to participate in the study by giving written informed consent. 


\subsection{Exclusion criteria:}

1. Patients with previous history of TIA/CVA.

2. Patients who are on thiazide diuretics.

3. Patients who are known cases of gout or show clinical evidence of gout.

4. Patients with chronic renal failure.

5. Patients whose CT scan show haemorrhage or other space occupying lesions other than infarct.

6. Patients with haematological abnormalities like leukemia or other myeloproliferative disorders.

\subsection{Methodology:}

A total 100 consecutive patients (50 males and 50 females) who met the inclusion and exclusion criteria during the study period with first episode of stroke as evidenced by CT scan within 48 hours were chosen for the study. Blood sample was taken from all patients with acute stroke during 48 hours of admission to check serum uric acid by the Uricase / Phenol/ 4- Amino Phenazone (PAP) method in the Central Laboratory of SVRRGGH, Tirupati. (Normal uric acid levels in females $2.4-6.0 \mathrm{mg} / \mathrm{dl}$, males $3.4-7.0$ $\mathrm{mg} / \mathrm{dl}$ ).The patients are evaluated for the presence of additional risk factors such as

\section{Hypertension:}

a] Known case of hypertension b] Blood pressure > 140/90 mm of Hg.

2. Diabetes Mellitus:

a] Known case of diabetes mellitus b] Random blood sugar > $200 \mathrm{mg} / \mathrm{dl}$ and / or Fasting blood sugar > 126 $\mathrm{mg} / \mathrm{dl}$ and Post prandial blood sugar $>200 \mathrm{mg} / \mathrm{dl}$.

\section{Coronary Heart Disease:}

Patients with ECG (Electrocardiogram) evidence of infarction or Echocardiogram showing regional wall motion abnormalities.

\section{Adverse Lipid Profile:}

a] Total cholesterol -> $200 \mathrm{mg} / \mathrm{dl}$ b] Triglycerides - > $150 \mathrm{mg} / \mathrm{dl} \mathrm{c]} \mathrm{LDL-Cholestrol} \mathrm{-} \mathrm{>} 130 \mathrm{mg} / \mathrm{dl}$ d] HDLcholestrol - < 40mg/dl

\section{Smoking And Alcoholism:}

History of smoking and alcoholism within the last 5 years has been taken as smokers and alcoholics.

\subsection{Statistical analysis:}

The study results were analysed using Epi Info 7 Software Version:

Calculation of frequencies, percentage, mean and standard deviation

Unpaired Student ' $t$ ' test was applied wherever appropriate.

$\mathrm{p}$ value calculation for statistical significance (less than 0.05 )

\section{Results}

Table 1: Age distribution of ischemic stroke patients according to sex

\begin{tabular}{|l|c|c|}
\hline \multirow{2}{*}{$\begin{array}{l}\text { AGE } \\
\text { YEARS }\end{array}$} & \multicolumn{2}{|c|}{ PATIENTS } \\
\cline { 2 - 3 } & MALE & FEMALE \\
\cline { 2 - 3 } & NO. & NO. \\
\hline$<40$ & - & - \\
\hline $40-49$ & $8[16 \%]$ & $11[22 \%]$ \\
\hline $50-59$ & $20[40 \%]$ & $6[12 \%]$ \\
\hline $60-69$ & $13[26 \%]$ & $22[44 \%]$ \\
\hline $70-79$ & $7[14 \%]$ & $9[18 \%]$ \\
\hline $80 \&$ above & $2[4 \%]$ & $2[4 \%]$ \\
\hline Total & $50[50 \%]$ & $50[50 \%]$ \\
\hline
\end{tabular}

The mean age of the male patients was $59.1 \pm 10.2$ years and of the female patients was $60.5 \pm$ 11.1years .

Table 1 showed $50 \%$ were males and 50\% were females. The majority of the stroke patients were presented between 50 to 69 years accounting to $61 \%$ of patients with 33 males and 28 females.

Table 2: Distribution of serum uric acid levels among ischemic stroke patients:

\begin{tabular}{|c|c|}
\hline $\begin{array}{l}\text { SERUM URIC ACID } \\
\text { LEVELS (mg\%) }\end{array}$ & $\begin{array}{l}\text { PATIENTS NUMBER } \\
(\%)\end{array}$ \\
\hline$<7$ & $75(75 \%)$ \\
\hline$\square 7$ & $25(25 \%)$ \\
\hline Total & $100(100 \%)$ \\
\hline
\end{tabular}


Mean serum uric acid level in stroke patients was $5.58 \pm 1.68 \mathrm{mg} / \mathrm{dl}$. Table 2 showed Hyperuricemia $(7$ or more than $7 \mathrm{mg} / \mathrm{dl}$ ) was present in $25 \%$ of Stroke patients.75\% Stroke patients had less than $7 \mathrm{mg} / \mathrm{dl}$ of serum uric acid.

Out of 25 hyperuricemia in stroke patients, $11(68.8 \%)$ patients were between $70-79$ years old. Hyperuricemia was associated in $25 \%$ stroke patients with $24 \%$ (12) males and $26 \%$ (13) females.

Table 3: Age and mean serum uric acid (mg/dl) levels according to sex among ischemic stroke patients

\begin{tabular}{|l|c|c|}
\hline $\begin{array}{l}\text { AGE IN } \\
\text { YEARS }\end{array}$ & $\begin{array}{l}\text { MEAN SUA LEVELS } \pm \text { SD IN } \\
\text { MALES }\end{array}$ & $\begin{array}{l}\text { MEAN SUA LEVELS } \pm \text { SD IN } \\
\text { FEMALES }\end{array}$ \\
\hline $40-49$ & $4.4 \pm 1.7$ & $4.5 \pm 0.7$ \\
\hline $50-59$ & $5.1 \pm 1.5$ & $4.97 \pm 1.3$ \\
\hline $60-69$ & $5.6 \pm 1.4$ & $5.7 \pm 1.5$ \\
\hline $70-79$ & $7.3 \pm 1.97$ & $7.2 \pm 1.45$ \\
\hline $80 \&$ above & $8.4 \pm 0.0$ & $4.8 \pm 0.85$ \\
\hline 'p'value & $\begin{array}{l}\text { 0.001; Significant } \\
\text { (unpaired ' } t \text { ' test) }\end{array}$ & $\begin{array}{c}\text { 0.001; Significant } \\
\text { (unpaired 't' test) }\end{array}$ \\
& & \\
\hline
\end{tabular}

Table 3 showed the mean uric acid value for 40-49 years group was $4.46 \mathrm{mg} / \mathrm{dl}$ while the elderly age group of above 70 years had the mean value $7.2 \pm 1.45 \mathrm{mg} / \mathrm{dl}$. Age wise distribution of uric acid was found statistically significant. As age advances the uric acid level also rises with the ' $\mathrm{p}$ " of $<0.001$. The significance was maintained even when male and female populations were considered separately (" $p$ " of 0.001 for males and 0.001 for females).

In the present study overall $65 \%$ patients were hypertensive and $35 \%$ patients were non hypertensive. Out of 25 hyperuricemic patients, $20(80 \%)$ patients were hypertensive, whereas in patients with normal level of serum uric acid $45(60 \%)$ out of 75 were hypertensive. The mean uric acid level in hypertensive population was $5.78 \pm 1.66 \mathrm{mg} / \mathrm{dl}$ and in non hypertensive population was $5.18 \pm 1.658 \mathrm{mg} / \mathrm{dl}$. This study does not show significant association between hypertension and uric acid.

Among the patients $51 \%$ were diabetic and $49 \%$ patients were non diabetic. Out of 25 hyperuricemic patients $17(68 \%)$ were diabetic, whereas in patients with normal level of serum uric acid $34(45.3 \%)$ out of 75 were diabetic.

Table 4: Ischemic stroke patients with diabetes mellitus and mean serum uric acid levels

\begin{tabular}{|l|c|}
\hline \multirow{2}{*}{$\begin{array}{l}\text { PATIENTS WITH } \\
\text { DIABETES } \\
\text { MELLITUS }\end{array}$} & SERUM URIC ACID $(\mathrm{mg} / \mathrm{dl}$ ) LEVEL \\
\cline { 2 - 2 } Present & $\mathbf{6 . 1 2} \pm 1.64$ \\
\hline Absent & $5.02 \pm 1.54$ \\
\hline ' $p$ ' value & $\begin{array}{l}\text { 0.001; Significant } \\
\text { (Unpaired 't' test) }\end{array}$ \\
\hline
\end{tabular}

Table 4 showed a statistically significant association ('p' value of 0.001 ) found between the level of uric acid and Diabetes mellitus. Among diabetic the mean uric acid value was $6.12 \pm 1.64 \mathrm{mg} / \mathrm{dl}$ while among non diabetic was $5.02 \pm 1.54 \mathrm{mg} / \mathrm{dl}$.

This association was more significant among males ( $p$ value of 0.008) among whom the diabetics have $6.3 \pm 1.84 \mathrm{mg} / \mathrm{dl}$ as mean uric acid level compared to non diabetics, $4.9 \pm 1.55 \mathrm{mg} / \mathrm{dl}$ as mean value. But, this association was not found significant in female patients.

Out of 100 patients $32 \%$ of them had CAD and $68 \%$ patients were without CAD. Out of 25 hyperuricemic patients, $17(68 \%)$ patients were CAD, whereas in patients with normal level of serum uric acid $15(20 \%)$ out of 75 were without CAD. 
Table 5: Ischemic stroke patients with coronary artery disease and mean serum uric acid levels

\begin{tabular}{|l|c|}
\hline \multirow{2}{*}{$\begin{array}{l}\text { PATIENTS WITH } \\
\text { CAD }\end{array}$} & SERUM URIC ACID (mg/dl) LEVEL \\
\cline { 2 - 2 } Present & MEAN \pm S.D \\
\hline Absent & $5.1 \pm 1.9$ \\
\hline 'p' value & $\begin{array}{c}\text { 0.0001; Significant } \\
\text { (Unpaired 't' test) }\end{array}$ \\
\hline
\end{tabular}

Table 5 showed mean uric acid level in the stroke patients with Coronary artery disease was $6.5 \pm$ $1.9 \mathrm{mg} / \mathrm{dl}$ and in those without Coronary artery disease was $5.1 \pm 1.4 \mathrm{mg} / \mathrm{dl}$ and thus established a statistically significant relationship ( $\mathrm{p}$ value of $<0.0001$ ). When males and females were considered, males have a significant association with a $\mathrm{p}$ value of $<0.0001$. Female population didn ${ }^{\text {ee }}$ show such association.

Out of 100 patients $34 \%$ of them had adverse lipid profile and $66 \%$ patients had normal lipid profile. Out of 25 hyperuricemic patients $12(48 \%)$ had adverse lipid profile, whereas in patients with normal level of serum uric acid $22(29.3 \%)$ out of 75 had normal lipid profile.

Mean uric acid level in hyperlipidemic stroke population was $5.8 \pm 1.87 \mathrm{mg} / \mathrm{dl}$ and compared to $5.5 \pm 1.57 \mathrm{mg} / \mathrm{dl}$ mean uric acid level in patients without hyperlipidemia didn ${ }^{\text {ee }}$ show any statistically significant relationship. There was no statistically significant relationship even when males and females were analysed separately.

In the present study among 50 male patients, $34(68 \%)$ were smokers and 16(32\%) were non smokers. Out of 12 hyperuricemic patients 7(20.6\%) patients were smoker. $27(79.4 \%)$ patients were smokers had normal serum uric acid levels out of 38 patients.

Mean uric acid level in smokers was $5.25 \pm 1.74 \mathrm{mg} / \mathrm{dl}$ and among non smokers were 5.75 \pm 1.63 $\mathrm{mg} / \mathrm{dl}$. Thus in this study there was no statistically significant relationship between smoking and uric acid.

In the present study among 50 male patients, $19(38 \%)$ were alcoholic and 31(62\%) were non alcoholic. Out of 12 hyperuricemic patients, 4 (33.3\%) patients were alcoholic. 15 (39.5\%) patients were non alcoholic have normal serum uric acid levels out of 38 patients.

Mean uric acid level in alcoholic patients was $5.4 \pm 1.83 \mathrm{mg} / \mathrm{dl}$ and among non alcoholic patients was $5.6 \pm 1.65 \mathrm{mg} / \mathrm{dl}$. Thus in this study there was no statistically significant relationship between alcoholism and uric acid.

Table 6: Serum uric acid levels (in $\mathrm{mg} / \mathrm{dl}$ ) and size of lesion in ischemic stroke patients

\begin{tabular}{|l|l|c|}
\hline \multirow{2}{*}{ SIZE OF LESION } & \multicolumn{2}{|l|}{$\begin{array}{l}\text { SERUM URIC ACID }(\mathrm{mg} / \mathrm{dl}) \\
\text { LEVEL }\end{array}$} \\
\cline { 2 - 3 } & $<7$ & $\square 7$ \\
\hline Small $(<3 \mathrm{~cm})$ & $63(92.6 \%)$ & $5(7.4 \%)$ \\
\hline Large $(>3 \mathrm{~cm})$ & $12(37.5 \%)$ & $20(62.5 \%)$ \\
\hline Total & 75 & 25 \\
\hline
\end{tabular}

Table 6 showed $32 \%$ of the patients have large infarct and $68 \%$ have small infarct. Out of 25 hyperuricemic ( $\geq 7 \mathrm{mg} / \mathrm{dl}$ ) patients, $20(62.5 \%)$ patients have large infarct in CT scan brain. $12(37.5 \%)$ patients with large infarct have normal serum uric acid levels $(<7 \mathrm{mg} / \mathrm{dl})$ out of 75 patients.

Table 7 : Mean serum uric acid levels and size of infarct in ischemic stroke patients

\begin{tabular}{|l|c|}
\hline \multirow{2}{*}{ SIZE OF INFARCT } & SERUM URIC ACID $(\mathrm{mg} / \mathrm{dl})$ LEVEL \\
\cline { 2 - 2 } & MEAN \pm S.D \\
\hline Small $(<3 \mathrm{~cm})$ & $4.816 \pm 1.258$ \\
\hline Large $(\approx 3 \mathrm{~cm})$ & $7.20 \pm 1.251$ \\
\hline 'p' value & $\begin{array}{l}0.0001 \text {; Significant } \\
\text { (Unpaired 't' test) }\end{array}$ \\
\hline
\end{tabular}


Table 7 showed mean serum uric acid level in small infarct was $4.816 \pm 1.258 \mathrm{mg} / \mathrm{dl}$ and in patients with large infarct mean serum uric acid level was $7.2 \pm 1.251 \mathrm{mg} / \mathrm{dl}$. The ' $\mathrm{p}$ ' value was $<0.0001$ and the results were statistically significant.

\section{Discussion}

Most epidemiological studies have reported significant association between elevated SUA and increased cerebrovascular disease. ${ }^{3,4}$ UA is one of most important antioxidants in serum and appears to be neuroprotecive in animal models, the results from human studies are controversial. ${ }^{7}$ Serum UA levels would change noticeably in association with degree of oxidative stress in acute ischemic stroke.

Present study was conducted on a total of 100 (50 males and 50 females) patients who were diagnosed to have acute ischemic stroke based on clinical features and CT scan of brain.

In the present study, patients were in the age group of 40- 84 years. Commonest age group observed was 50 - 69 years $(61 \%)$ and the mean age was $59.8 \pm 10.6$. Mean SUA in acute ischemic stroke patients was $5.58 \pm 1.68 \mathrm{mg} / \mathrm{dl}$ and about $25 \%$ patients were hyperuricemic. Mean SUA value for $40-49$ years age group was $4.4 \mathrm{mg} / \mathrm{dl}$ while elderly age group of above 70 years has the mean value was $7.2 \mathrm{mg} / \mathrm{dl}$. Age wise distribution of uric acid was found statistically significant $(p<0.001)$ and the association was maintained even when both sexes were considered separately. Among diabetics the mean uric acid value was $6.12 \pm 1.64 \mathrm{mg} / \mathrm{dl}$ while among non diabetics it was $5.02 \pm 1.54 \mathrm{mg} / \mathrm{dl}$, among in CAD patients it was $6.5 \pm 1.9$ $\mathrm{mg} / \mathrm{dl}$ and in those without CAD was $5.1 \pm 1.4 \mathrm{mg} / \mathrm{dl}$; Among the patients with large infarct was $7.2 \mathrm{mg} / \mathrm{dl}$ compared to those with small infarct was $4.816 \mathrm{mg} / \mathrm{dl}$ and thus established a statistically significant relationship ( $\mathrm{p}$ value of $<0.0001$ ). When males and females were considered, males have a significant association with CAD $(\mathrm{p}<0.0001)$ and diabetic $(\mathrm{p}<0.008)$ patients. Female population didn ${ }^{\text {ee }} \mathrm{show}$ such association. There was no stastically signicant association between hypertension, hyperlipidemia, smoking, alcoholism and uric acid levels.

\section{The Results Of Present Study Were Correlated With The Results Of Available Studies In Literature:}

Mangal et al, ${ }^{8}$ Bansal et al, ${ }^{9}$ Masoud et al ${ }^{10}$ has reported the prevalence of hyperuricemia of $29 \%, 30 \%$, $47.3 \%$ respectively in patients with acute ischemic stroke.

Milionis et al, ${ }^{4}$ Masoud et al, ${ }^{10}$ Patil et al, ${ }^{11}$ Bansal et al $^{9}$ has reported that mean SUA of $5.6 \pm 1.7$ $\mathrm{mg} / \mathrm{dl}, 5.94 \pm 1.7 \mathrm{mg} / \mathrm{dl}, 6.48 \pm 1.92 \mathrm{mg} / \mathrm{dl}, 8.94 \pm 2.37 \mathrm{mg} / \mathrm{dl}$ respectively in study population.

Milionis et $\mathrm{al}^{4}$ studied 163 patients above 70 years studied for association of SUA and stroke concludes that SUA was associated with an increased risk for acute ischemic/ non embolic stroke in elderly patients independently concludes metabolic derangements. In Patil et al ${ }^{11}$ study, mean SUA value for $<50$ years age group was $5.43 \pm 1.98 \mathrm{mg} / \mathrm{dl}$ while elderly age group of $\geq 70$ years had the mean value was $5.88 \pm$ 1.56.The SUA levels increased with increasing age but this correlation was not statistically significant.

Patil et al, ${ }^{11}$ Longo- Mbenza et al, ${ }^{12}$ Singh et al $^{13}$ has reported that the serum uric acid levels were higher in diabetic patients as compared to nondiabetic stroke patients and a significant association was found between diabetic status of ischemic stroke patients and elevated uric acid levels $(p<0 \cdot 05)$.

Rotterdam ${ }^{14}$ study which had 4385 participants with follow up of 8.4 years showed that SUA is a strong risk factor for myocardial infarction and stroke. A study by Freedman et al ${ }^{15}$ reported that hyperuricemia often exists in patients with ischemic heart disease and it can be a risk factor for these diseases.

Masoud et $\mathrm{al}^{10}$ has reported there was no significant association between hypertension,smoking and serum uric acid level $(\mathrm{p}>0.05)$.

Mangal et al, ${ }^{8}$ Chamorro et $\mathrm{al}^{5}$ has reported insignificant relationship between dyslipidemia and serum uric acid in patient with acute ischemic stroke.

Patil et $\mathrm{al}^{11}$ study reported that SUA levels were also higher in patients with large artery stroke as compared to those with lacunar stroke but this difference was not found to be statistically significant $(6.73 \pm 2.07$ vs. $6.16 \pm 1.68 \mathrm{mg} / \mathrm{dl}, \mathrm{P}=0.145)$.

\section{Conclusions}

The prevalence of hyperuricemia in acute ischemic stroke patients in present study was $25 \%$. Age wise distribution of uric acid was found statistically significant. As age advances uric acid also rises. There was a statistically significant association between levels of uric acid and diabetes mellitus, CAD, larger infarct size patient. There was no stastically signicant association among the hypertension, hyperlipidemia, smoking, alcoholism patients and uric acid levels. 


\section{References}

[1]. Wade S. Smith, S. Claiborne Johnston, J. Claude Hemphill, III. Cerebrovascular diseases. In: Longo DL, Fauci AS Kasper DL, Hauser SL et al. Harrison “e s Principles of Internal Medicine. 19thed. Philadelphia Mc Graw Hill; 2015.2559 - 84.

[2]. Buckley BM. Healthy aging: ageing safely. Eur Heart J 2001; (suppl. 3): N6-10

[3]. Daskalopoulou SS, Athyros VG, Elias M, Mikhailidis DP. Uric acid levels and vascular disease: Curr Med Res Opin 2004;20:951-4

[4]. Milionis HJ, Rizos E, Goudevenos J, Seferiadis K, Mikhidilis DP, Elisaf MS. Component of the metabolic syndrome and risk for first-ever acute ischemic non-embolic stroke in elderly subjects. Stroke 2005; 36:1372.

[5]. Chamorro A, Obach V, Cervera A, Revilla M, Deulofeu R, Aponte JH. Prognostic significance of uric acid serum concentration in patients with acute ischemic stroke. Stroke 2002; 33:1048-1052.

[6]. Dawson J, Quinn T, Lees K,Walters M: The Continued Yin and Yang of Uric Acid, Stroke 2008;39;e9; originally published online Nov 29, 2007;

[7]. Amaro S,Urra X, Gomez-Choco M, et al. Uric acid levels are relevant with in patients with stroke treated with thrombolysis. Stroke 2011;42(1):S28-S32.

[8]. Mangal AC, Guria RT, Singh MK. Serum uric acid level in acute ischemic stroke. Journal of Evolution of Medical and Dental Sciences. 2013; 2 (36): 6915-26.

[9]. Bansal BC, Gupta RR, Bansal MR, et al. Serum lipids and uric acid relationship in ischemic thrombotic cerebrovascular disease. Stroke. 1975;6:304-307.

[10]. Masoud M, Khuzan M, Najimi N, Motamed MR, Fereshtehnejad SM. Serum uric acid level in acute stroke patients. Med J Islam Repub Iran. 2012; 26(2): 66-72.

[11]. Patil TB, Pasari AS, Sargar KM, Shegokar VE, Bansod YV, Patil MB. Serum uric acid levels in acute ischemic stroke: A study of 100 patients. J Neurol Res 201; 1(5): 193-200. 67.

[12]. Longo-Mbenza B, Luila EL, Mbete P, Vita EK. Is hyperuricemia a risk factor of stroke and coronary heart disease among Africans?. Int J Cardiol. 1999 ; 71(1): 17-22.

[13]. Singh AS, Atam V, Das L, Koonwar S. Role of uric acid in ischemic stroke and its association with carotid atherosclerosis. JIMR. 2013; 1(2): 32-38. 38.

[14]. Bos MJ, Koudstaal PJ, Hofman A, Witteman JCM, Breteler MMB. Uric acid is a risk factor for myocardial infarction and stroke. The Rotterdam study. Stroke. 2006; 37: 1503-1507.

[15]. Freedman DS, Williamson DF, Gunter EW, et al. Relation of serum uric acid to mortality and ischemic heart disease. The NHANES I epidemiologic followup study. Am J Epidemiol. 1995;141: 637-44. 